\title{
Relocating Self-Translation from the Interlingual to Intralingual: Faulkner as a Self-Translauthor
}

\author{
Gülsüm CANLI ${ }^{*}$
}

American author William Faulkner (1897-1962) rewrites his book Sanctuary (1931) as the editor turns down the first manuscript claiming that they both would be jailed if it is published. In the source literary system, the discussion about the rewriting is confined to two reasons: the issue of morality and the artistic flaws in the original text. The point of departure in the present article, which aims to explore this rewriting process within the context of translation studies, is André Lefevere's definition. Lefevere states that "every translation is a rewriting" (1992, vii). Considering this widely-accepted definition, this paper pursues an answer to the following questions: Is it (im)possible to call a 'rewriting' a translation? And if the 'rewriting' is within the same language, can we call it an 'intralingual translation?' As Faulkner rewrites his own text himself, could this be a 'self-translation' as well?. 'Self-translation' is defined with reference to a bilingual writer who writes his own text in another language. If bilingualism is imperative for 'self-translation', then, is it (im)possible to call it a 'self-translation' when a writer rewrites his own text in the same language? The question whether the analyzed case can be regarded as an 'intralingual self-translation' will be examined according to Gideon Toury's translation norms. A comparative textual analysis of the original text and the revised text will be carried out to display the findings that will be discussed in the framework of Toury's method for descriptive translation studies.

Keywords: intralingual translation; self-translation; rewriting; translation norms; translauthor

\section{Problematizing Concepts: Intralingual Translation and Self-Translation Revisited}

In this part of the study, an overview of 'intralingual translation' and 'self-translation' will be provided to explore the content and the limits of these concepts within the context of translation studies.

\subsection{Intralingual Translation}

Defining translation as a linguistic transfer between two languages may summarize the common perception but this would overlook the broad discussion within translation studies concerning the definition of translation. This limited definition refers to only one of the three

\footnotetext{
${ }^{*}$ Instructor at Istanbul University, Istanbul; PhDc at Yıldız Technical University, Istanbul. E-mail: canligulsum@gmail.com
} 
kinds Russian linguist and literary theorist Roman Jakobson (1959) discusses in his paper entitled "On Linguistic Aspects of Translation" (232-239). Other than "interlingual translation," or "translation proper," Jakobson expands the discussion with "intralingual" and "intersemiotic translations". The former is called "rewording" and means "the interpretation of verbal signs by means of other signs of the same language" while the latter is called "transmutation" and means "the interpretation of verbal signs by means of signs of nonverbal sign system" (114).

Jakobson's division is believed to be broad and inclusive, but the wording in this classification is controversial. In his division, Jakobson tries to explain the two sub-categories - 'intralingual and intersemiotic translation' - but not 'interlingual translation.' His explanation is believed to make a comparison between "a translation in the proper sense" and "a translation in the figurative sense" (Derrida 1985, 174). Jacques Derrida (1985) argues that Jakobson translates "intralingual translation" as "rewording" and "intersemiotic translation" as "transmutation" and he provides a "definitional interpretation" of translation for both (174). However, when it comes to 'interlingual translation,' he does not translate it but repeats the same word: 'interlingual translation or translation proper'. Derrida thinks that Jakobson expects people to understand what he means when he says 'interlingual translation' and that is why he does not feel the need to translate it. While one kind of translation is called "proper", Derrida believes that "the other uses of the word translation would be in a position of intralingual and inadequate translation, like metaphors, in short, like twists or turns of translation in the proper sense" (173-174). Theo Hermans (1997) agrees on the exclusive wording of Jakobson's trilogy and states that “. . . there translation is translation proper, and only that" (17). On one hand, the trilogy implies that a proper translation needs to be interlingual, but on the other hand, it includes two categories which are not normally meant by the term translation (18).

The wording is not the only controversial point in Jakobson's categorization. When it comes to 'intralingual and intersemiotic translation,' a reconsideration of the content and the scope is required for these two sub-categories. As for 'intralingual translation', Özlem BerkAlbachten claims that the notion of "rewording" is not adequate to describe the translational practices which exceed linguistic equivalence (cf. Berk-Albachten, 2019). Hence, it is possible to say that research into 'intralingual translation' needs a better-formulated context. For example, it is difficult to distinguish between languages and dialects or creoles and to 
draw boundaries between different historical stages of languages. In the case of Turkic languages such as Azerbaijani, Kazakh, Kirghiz, Turkoman, Uzbek, Tatar and Turkish, depending on the adopted point of view, translation between these languages can be either intralingual or interlingual because people, academics and institutions do not agree on whether these are dialects or distinct languages (Berk-Albachten 2014, 575). The scope of 'intersemiotic translation' needs to be reexamined as well. In her papers entitled "OkurYazar/Çizer Çevirmen (I-II)," Ayşe Banu Karadă̆ (2011a; 2011b) analyzes an album of cartoons, Çeviren Latif Demirci published in 1996. The book comprises paintings of famous artists such as Botticelli, Picasso, Van Gogh and Renoir. The cartoonist Latif Demirci, as he terms his act, has translated these world-wide famous artists' paintings. As he calls his work a translation, Karadağ believes that it is worth discussing what kind of a translation his work is and how it needs to be handled within the context of translation studies (2011a, 5). A detailed analysis displays that the album of cartoons does not exemplify Jakobson's definition of intersemiotic translation and does not fit into the available categories (2011b, 9). With reference to Toury's notion of 'assumed translation,' Karadağ (2010b) looks into how Demirci's cartoons prove to be a translation under the conditions of the target culture as Demirci's cartoons are believed to include both universal and local elements and the paintings in the album of cartoons bear his signature (691).

Even if "intralingual" and "intersemiotic translations" are accepted in translation studies, these two are still regarded as "peripheral or de facto" (Zethsen 2009, 797). The subcategories of 'intralingual' and 'intersemiotic translation' are not dismissed but scholars tend to restrict their research with translation proper. However, Turkey stands out as a context where the research on 'intralingual translation' is overwhelming because of the language reform of 1928, an act of language planning which changed both the alphabet and the language itself. This change which transformed Turkish society "can also be seen as a translation process, for it mostly affected the language of translated literature and of the Turkish literature of the republican era" (Berk-Albachten 2015, 166). Although this field of research is not new for Turkish literature experts, as a translation material, it leads to new rereadings within the context of translation studies.

Among the available analyses based on various texts, there are some with complicative results which are specific to 'intralingual translation.' In her essay entitled "Intralingual Translation: Discussions within Translation Studies and the Case of Turkey," Özlem Berk- 
Albachten (2014) discusses that the rewritten Turkish literary works that she analyses in her study are not labeled as translations but "reproductions of originals." However, the findings display that the simplified and rewritten versions are subjected to "a covert translation process," on which "the cultural, political, and ideological agendas of the editors, publishers, and translators play a major role" (581).

In another study which also focuses on re-editions of Turkish literary works, Esra BirkanBaydan (2011) regards "editing" as a translating practice and states that the broader category of "rewriting" also covers "editing" (53). She concludes that "even the critical editions which do not involve direct intralingual translation are rewritten texts" (65). However, the conceptualization in the conclusion raises some questions. If some editions do not involve 'direct intralingual translation', then, it is possible to say that they involve 'indirect intralingual translation.' But these editions are still considered 'rewritten texts' instead of 'intralingual translations.' The reason why the critical editions are called 'rewriting' rather than 'intralingual translation' can be explained with the vague nature of 'intralingual translation.'

In a case study entitled "Intralingual Translation: An Attempt at Description", Karen Koning Zethsen (2009) tries to come up with a general definition of 'intralingual translation' and its characteristics on the basis of five different Danish versions of a section of the Bible. She analyzes the micro-strategies employed in each version and believes that "the microstrategies applied in intralingual translation (the editions, omissions, restructuring, etc.) seem to be much more radical than what is seen in the majority of interlingual translations" (809).

In the revision of Sanctuary, micro-strategies have been used seriously throughout the novel. For example, the book is restructured from the very first page and the following chapters are full of examples of editions and omissions. Therefore, regarding the novel's revision only as an 'editing' would be simplistic. However, Sanctuary does not set an example for any of the 'intralingual translation' categories, either. In his essay "Multidimensional Translation: Semantics Turned Semiotics," Henrik Gottlieb (2005, 4) divides ‘intralingual translation' into four categories:

- diachronic translation (between different historical stages of the same language),

- dialectal translation (between different geographical, social or generational variants of the same language),

- diamesic translation (implying a change in language mode; i.e. from speech to writing or vice versa), 
- transliteration (which involves a change in alphabet)

Although the revision of Sanctuary cannot be explained with reference to any of the sub-categories above, it could still be possible to consider it an 'intralingual translation', because the given categories may not suffice to cover all the examples of intralingual translation' and there might be a need to add other categories. In the article "Çevirmen ve Düzeltmen/Yayın Yönetmeni Dipnotlarıyla Osmanlı Tarihi'ni Yeniden Yazmak: Diliçi ve Dillerarası Çeviri Örneği,” Ayşe Banu Karadağ (2011), analyzes the well-known French writer Alphonse-Marie-Louis de Prat de Lamartine's L'Histoire de la Turquie in terms of translator's and redactor's/ editor's notes. The analysis is based on the examples where the translator and the redactor/ editor comment on the accuracy of the historical information in the translated texts. While the translator renders an interlingual translation, the editor comments on both the translated text and the translator's notes. Hence the redactor/editor provides a different reading via footnotes, which can be called an "intralingual translation" (243). The footnote analysis is not included in the given categorization as an example of 'intralingual translation,' so it is possible to say more sub-categories may be needed as the field of research looks into different cases.

In order to contribute to the discussions given within the scope of the studies above, this paper aims to analyze the revision of Sanctuary. The findings are believed to expand the definition of 'intralingual translation' and shed light on the similarities and differences between 'intralingual translation' and 'rewriting' with a focus on the author's translational actions as the translator of his/her own text. In order to understand and expand this focus, the next chapter will continue with a discussion on 'self-translation.'

\subsection{Self-Translation}

Self-translation can refer "both to the act of translating one's own writings into another language and the result of such an undertaking" (Grutman 2009, 257). In literary studies and translation studies, little attention has been paid to 'self-translation' mostly because of two reasons: "linguistic purity" and "conceptual problems" (Hokenson and Munson 2007, 1-2). The insistence on linguistic purity results from the western attitude which has always been in favor of "nationalistic monolingualism" at the expense of ignoring "the intercultural origins of literary innovation," Hokenson and Munson $(2007,2)$ claims. Conceptual problems arise 
because of the monolingual notions such as 'author' and 'original', which are questionable within the bilingual context of 'self-translation' (2). Scholars' disagreement on 'selftranslation' raises several questions such as :"Are the two texts both original creations? Is either text complete? Is 'self-translation' a separate genre? Can either version belong within a single language or literary tradition? How can two linguistic versions of a text be commensurable?" (2).

Basically because of these theoretical disagreements, there is a lack of comprehensive research on 'self-translation' and most of the available studies are based on the following with a focus on the differences between the first and the second text:

- a single (or a few) authors such as Nabokov, Beckett or Julien Green

- post-colonial studies

- $\quad$ some writers issued from a linguistic minority such as Catalan, Yiddish, Chicano

- $\quad$ exiled or migrated subject such as Hannah Arendt, Klaus Mann

- a personal account of the self-translator's experience

- $\quad$ self-translation from dialects (as in Italy) (Montini 2010, 307)

The focus on the differences between the first and the second text open a discussion for "the intertextual dialogue between the original and the translation, or between two parallel texts" (Sindicic-Sabljo 2011, 168). Some scholars believe that "the act of translation allows the bilingual writer to revisit and improve on earlier drafts in the other language, thereby creating a dynamic link between both versions that effectively bridges the linguistic divide" (Grutman 2009, 259). The studies which addressed Beckett's bilingualism and questioned "the status of the second versions of his work" generally regard "Beckett's self-translations as texts which extend or amplify the original" (Sindicic-Sabljo 2011, 166-167). However, poststructuralist readings which do not credit an original text challenge the binary classifications. As Carolyn Shread has forcefully argued:

Self- translation reveals something about the nature of all translation and that is theoretically productive precisely because of its problematic status in relation to the binary categories by which translation is often defined: original/translation; author/translator; source text/target text. (Shread 2009, 51)

The binary oppositions are not helpful to understand 'self-translations' because the bilingual identity of the text is not observable in a single text. Hence, it is believed that the analysis may begin "at a level more basic than current binary theoretical model of gaps between texts, languages, and cultures" (Hokenson and Munson 2007, 4). Also, the discussion 
may be carried out "in some larger, and extra-textual framework that examines the author or the oeuvre as a whole" (Beer 1994, 217).

The discussions within 'self-translation' are not only on a textual level. The comparison between 'the self-translator' and 'the independent translator' leads to further disagreements. Some scholars believe that "self-translator is not a translator at all, because his texts are as original and authentic as those that preceded them" (Sindicic-Sabljo 2011, 165). The 'self-translator' is believed to hold a different status from an 'independent translator' as in the case of Waiting for Godot, Samuel Beckett's 1953 work. The play has been a vital part of the English Literature, however; it is the translation of En Attendant Godot, published in 1948. Beckett first wrote his play in French and then translated it into English. In his article, "Samuel Beckett and the Silent Art of Self-Translation," David Levey (1996) questions the authority of the 'self-translator' within this example and asks, "Can a neutral translator improve on the work of a "self-translator?"' Levey thinks that the answer is clearly "no" but also underlines the fact that it is difficult to answer "why". As in Beckett's case, even if there are "inaccuracies" and "inconsistencies" in the 'self-translation', "the author's own translation is not open to criticism, improvement or debate as the writer is the only one qualified to know what he wanted to say and how he wanted to express it" (55). However, there is a counterargument about self-translators' privilege and freedom, which is based on the idea that selftranslators also follow "the standard translation path" and "all of the phenomenon observed in self-translation are well-known translation procedures" according to Shlomit Ehrlich (2009, 254). 'Self-translators', like 'independent translators', omit, add, explicate and tone down (244). Hence, it is possible to say that the authority they have as writers do not liberate them from their responsibilities as translators.

To summarize the points above, it is possible to say that 'self-translations' are exposed to several debates because of the intertextual relations, monolingual conceptualizations and authorial responsibilities. What the present research would like to add to the discussion is whether a 'self-translation' can be intralingual rather than bilingual. What happens if a writer rewrites his own text in the same language? If André Lefevere's (1992) definition of translation, which says "every translation is a rewriting" (vii), is read backwards, "is it (im)possible to call a 'rewriting' a translation, or rather a 'self-translation' in our case?".

At first glance, the present research may seem to have a deductive approach as it departs from a definition for translation, but, actually, it speculates on this widely accepted 
definition. Deductive studies breed circular reasoning when researchers select a case which is already known to fall within the limits of a priori definition (cf. Toury 1995b, 142). However, the case picked for the analysis in the present research is not regarded as translational. With "an inductive attempt to derive general principles from the facts themselves" (Toury 1995b, 143), the present paper makes a textual comparison between the original and the revised texts and aims to understand a probable translational act.

The adventure of Sanctuary within the source culture cannot be explained by the theoretical rubrics of either 'intralingual translation' or 'self-translation.' However, the similarities it has with 'intralingual translation' and 'self-translation' are so obvious that it is not possible to call it a simple rewritten text. The present research aims to find out whether Faulkner's rewritten text can fit into a separate category as an example of translation.

\section{Theoretical Framework}

Definition and categorization of translation have always been a critical topic within translation studies because it is not easy to find an inclusive and explanatory definition for the act of translation. Jakobson's division which is based on linguistic paradigm, and therefore “word-oriented" (Sturrock 1991, 318), has been challenged by Gideon Toury who pioneered a paradigm shift in translation studies and discussed translation within the scope of cultural semiotics to get rid of Jakobson's pitfalls. According to Toury's classification (1986), basically there are two types of translation: "intersemiotic translation" and "intrasemiotic translation." The former is defined as the interpretation of a verbal sign by means of a nonverbal sign and the latter comprises both "interlingual and intralingual translations" (1112114).

As for the definition of translation, Toury's (1995a) target-oriented concept of "assumed translation" is as follows:

All utterances which are presented or regarded as such within the target culture, on no matter what grounds. Under such observation, there is no pretense that the nature of translation is given, or fixed in any way. What is addressed even in the longest run is not even what translation is in general, but what it proves to be in reality, and hence what it may be expected to be under various specifiable conditions. (32)

Toury (1995a) suggests that there are three conditions for a text to be viewed as an "assumed translation." The first one is the source text postulate which means a source text 
exists at some point in another culture or language. The second one is the transfer postulate which means there is a transfer process from a ST to a TT. And the final one is the relationship postulate which means there is intertextuality between two texts (33-35). Even if these three postulates are meant specifically for 'interlingual translation' and the discussion is based on different languages and cultures, it is possible to argue that they can easily be adapted for 'intralingual translation.' As in the case of Sanctuary, there is a transfer between a source and a target text in 'intralingual translation' where the intertextuality between the two texts is obvious and natural. The fact that this transfer takes place within the same language does not contradict with Toury's postulates because a language transfer is still plausible. Speaking the same language cannot be the sole unifying feature in a culture as there will always be several sub-groups. Therefore, it is possible to say a language transfer can take place within the same culture.

Toury (1995a) states that translating is not restricted to producing a target text based on a source text. On the contrary, the act of translating is a more complicated issue which involves socio-cultural elements. Hence, Toury regards translation as a norm-governed activity and puts the translation norms into three groups (54-55). The "initial norm" refers to the decision the translator makes about whether to subscribe to the norms of source culture or target culture. While the adoption of source culture norms results in an "adequate translation," the adoption of target culture norms results in an "acceptable translation." Toury emphasizes that "initial norm should not be overinterpreted" (57), because it would be unrealistic to expect a text to show absolute regularities as there might be shifts even in the most adequacyoriented translation.

The second group of norms is the "preliminary norms" which comprise translation policy and the directness of translation. Translation policy governs which texts should be translated. Different policies might exist depending on different text types or publishing houses. As for the directness of translation, the argument develops around whether the use of the ultimate source text is required or intermediate translations are permitted (58).

The final group of norms refers to "operational norms" that refer to the decisions during the act of translation. Operational norms are divided into two groups: "matricial norms" and "textual-linguistic norms." Matricial norms govern whether a translated text is complete or not. Omissions, reorganizations and additions are examples of decisions that refer 
to matricial norms. Textual-linguistic norms refer to the selection of linguistic material that produces the target text (58-59).

The main purpose of the present paper is to analyze a revised text, which can be regarded as an 'intralingual translation', using Toury's (1995a) theoretical framework. He explains that in descriptive translation studies it is possible to focus on works which could "plausibly have been regarded as translations but were not" (32). Taking Toury's opinions into consideration, the present paper may allow for some new insights into the rewriting and translating processes and norms in specific contexts.

\section{Data}

William Faulkner (1931) states that before he wrote Sanctuary, he searched for something that would sell a few thousand copies and fulfill his economic needs (vii-viii). This statement might explain why Faulkner calls Sanctuary "a cheap idea" (v), but Noel Polk, the editor of Sanctuary: The Original Text, published in 1981, thinks that Faulkner's statement undervalues this "remarkable and highly sophisticated" detective fiction. In his afterword for Sanctuary: The Original Text, Polk explains that the introduction Faulkner has composed for Sanctuary, published in 1931, is "deeply sardonic and self-deprecatory." Polk thinks that readers have managed to separate the fact from the fiction in the given introduction and the book is now thought to be one of Faulkner's great works (Faulkner 1981, 293).

In the source literary system, the text has undergone a sensational rewriting process. When the original manuscript was refused by the editor who warned the writer about a possible jail imprisonment, Faulkner had to rewrite it. The rewritten version was published in 1931 as Sanctuary. The original manuscript was published by the University of Texas in 1972; however, the text became easily accessible when Sanctuary: The Original Text was published in 1981 by Random House. Scholars have taken different stances towards why Faulkner had to rewrite it. Some scholars believe that Faulkner had to revise his text because it was artistically flawed. They believe that the revision has nothing to do with the morality of the text (Phillips 1988, 66). However, there is a second group who claim that the published version does not outperform the original version. They believe that the original text has its own integrity (Jaillant 2016, 142). None of the scholars have carried out a comparative study on the original and revised versions and the act of rewriting in the case of Sanctuary has not 
been discussed within the context of translation studies. A translation studies based approach in the present paper will contribute to the analysis of this rewriting act by expanding the discussion with 'intralingual translation' and 'self-translation.'

The novel is based on a case of rape and murder. The story takes place in the Prohibition Era during which the production and transportation of alcohol is prohibited. A 17year-old college student Temple Drake is taken to a distillery while she was planning to go to a school game with Gowan Stevens, a local bachelor who is proud of having received a university education in Virginia. There, she meets the landlord Lee Goodwin, his wife Ruby and his business partner Popeye. Temple and Gowan spend the night at the distillery because their car is broken. The following morning, Temple is raped and abducted by Popeye who also kills Tommy, another bootlegger. While Temple goes missing, Lee Goodwin is accused for the murder, but he neither accepts the charges nor tells the truth because he is afraid of Popeye. Horace Benbow is the lawyer who wants to defend Lee and help Ruby. He meets these people before the rape and murder takes place on his way to Jefforson, his hometown. Horace leaves his wife Belle and his step-daughter and returns to Jefferson where his sister, Narcissa lives. He learns about Temple when Ruby changes her mind and decides not to keep quiet anymore. Horace manages to find Temple in a brothel and persuades her to help Lee at the court. However, when Temple appears in the court, she gives a statement against Lee and the jury finds him guilty. Lee is lynched by the townspeople and Horace returns to his wife and step-daughter disappointed with his life.

\section{A Comparative Textual Analysis: Sanctuary The Original Text vs. Sanctuary}

Despite its debatable definition and context, many different instances within the scope of 'intralingual translation' offer scholars a great opportunity to analyze and explore this field of research. The present paper aims to understand an interwoven act of 'rewriting,' 'intralingual translation' and 'self-translation' in the frame of Toury's (1995a) descriptive translation studies. It may sound awkward to base an intralingual case on a theory which specifically focuses on interlingual translation, but there are studies which have already proved its possibility.

In the MA thesis "Is Change Necessary? A Study of Norms and Translation Universals in Intralingual Translation,” Anlaug Ersland (2014) studies translational shifts and 
norms in the American edition of a British book. Ersland finds out that this "transatlantic intralingual translation" is "subject to the same norms and shifts that are thought to influence interlingual translations" (88). The norms in the American edition "conform to the practices and policies of the target language and culture, thereby making the translation acceptable according to Toury's definition of the initial norm" (86).

In the article "Intralingual Intertemporal Translation as a Relevant Category in Translation Studies," Hilla Karas (2016) argues for "intralingual intertemporal translations" (IIT) as a separate category. The reason why IIT should be considered translation is based on Gideon Toury's two concepts: 'assumed translation' and 'translation postulates' (451-452). In the article, Karas aims to show that despite being marginalized in translation studies, 'intralingual translations' need a closer look to develop a more comprehensive definition and description of translation (462).

As for the case in the present study, from an essentialist point of view, the output of Sanctuary's revision process would be called a rewritten text. However, having reviewed the discussions of 'intralingual translation' and 'self-translation,' the paper aims to find out if it is possible to call the revised text 'an intralingual self-translation.' A textual comparison will be carried out to observe the differences and similarities between two texts and to understand the effects of the writer's decisions while revising the text. This textual comparison will be helpful to understand the initial norm as well as operational norms and preliminary norms.

\subsection{Structural Changes}

An apparent difference between the 1981 Sanctuary: The Original Text and the 1931 Sanctuary is narration. The revised text has been re-organized from the very first page. The original text starts with a scene from the jail where a negro who killed his wife sings a song by the jail window and patiently waits for the day of his execution. Meanwhile, in his cell, Goodwin experiences a mixture of feelings: pity for the negro, fear because of Popeye as he might shoot him with an automatic pistol through the window of his cell, worry for the future of his child and a dilemma whether Horace should defend him or not. The rest of the story is told anachronologically through flashbacks and flashforwards and the narration is mainly based on characters' memories, interpretations and tales. It is possible to say that Faulkner creates an illuminating stream of consciousness in the original text. 
The beginning scene of the revised text is taken from the second chapter of the original text where Horace encounters Popeye across a spring on his way to Jefferson. The rest of the story is told chronologically without the characters' intervention.

In the afterword, he writes for Sanctuary: The Original Text, the editor, Noel Polk states that "the opening scene in the revised version restructures the entire novel" (Faulkner 1981, 302). First of all, the narrative style changes. Faulkner does not make use of flashbacks anymore and from the beginning to the end, the story is straightforward. Secondly, in the revised version new relations develop between characters. Despite their differences, Horace and Popeye are given like mirror images through their reflections on the water. While they differ in their social status, family backgrounds and physical appearances, they have many things in common besides their encounter with Temple. According to Polk, both Horace and Popeye struggle with life and become victims of injustice (Faulkner 1981, 304). At the end, while Horace loses Lee's case, Popeye is convicted for a crime he has not committed.

While Horace and his Freudian problems are the primary concern in the original text, Popeye moves to a more central role in the revised text because of structural changes. As characters' significance changes within the text, so does the main theme in the revised text. The primary concern is not Horace's Freudian problems anymore. Faulkner gets out of "Horace's cloyingly introspective, narcissistic personality" (Faulkner 1981, 300). The revised text is mainly concerned with "the nature of evil itself: the power of darkness, the insufficiency of light" (Faulkner 1981, 304).

In his overall assessment, Polk believes that the revised version is "smoother and faster-paced" (Faulkner 1981, 304). The editor summarizes the changes in the following paragraph:

The manuscript contains not only the usual deletions and additions and minor stylistic emendations one expects to see in such a document; on many pages are pasted long passages scissored from other, earlier pages, sometimes two or three such passages per page; and nearly all pages were shifted during the writing, as Faulkner experimented with scene and structure, juxtaposed scene against scene, character against character, chapter against chapter, decided against the effect produced by a particular juxtaposition, then tried again; one page bears twenty-two different pages. (Faulkner 1981, 294-295)

Based on the assessment above, it is possible to say that the revised text has been thoroughly restructured. The former manuscript was more complicated because of the 
anachronological sequence of events, long passages and the subjective point of view based on the characters' perspective. The revised text is disposed of these elements to produce a straightforward text. From the very first scene, Faulkner's revision of Sanctuary, has changed the stylistic features, the thematic concerns and relations between characters.

\subsection{Additions}

Faulkner has added a long biography of Popeye to the end of the revised book. With this addition, the reader is informed about his run-away father, mentally instable grandmother who burnt down their house, Popeye's sadistic attitude towards animals and his invalid mother. Readers also learn that Popeye was not a healthy child: He had no hair until he was five, his stomach was sensitive, had no friends and had always been impotent. The details about Popeye's desperate life are not given to encourage the reader to empathize with him. The biography needs to be discussed together with the revised beginning and the changing theme of the novel.

Firstly, the information about Popeye's past is vital to bring him to a more central role. As the opening of the revised text centralizes Popeye, the last chapter wraps up his story. The original text contains no information about Popeye's childhood and family. Without Popeye's biographical information, Horace would preserve the central role as the original text already contains a lot of information about his family background and private life.

Also, the details in the biography help to support the changing theme of the novel. Popeye's father left him and his mother before he was born so he was an illegitimate child. His mother who worked hard to bring up her son was cheated by her second husband and lost all her savings. His grandmother burned down their house and died in the fire. His mother never recovered from this incident believing that her son also died in the fire. Popeye always had health problems. He started torturing and killing animals when he was a young boy and was sent to a home for incorrigible children where he stayed for five years. Popeye did not lead a decent life as an adult, either and became a bootlegger. In the novel, he is repeatedly described as "a black figure" in his black suit (Fowler 2004, 422). With his appearance and the additions about his past, he is described like the evil itself in the form of a human being. And this evil figure determines the main theme of the revised text.

\subsection{Deletions}


Faulkner has deleted a serious amount of information about Horace's relation with his sister while revising the original text. While the relationship between Horace and his sister is obscure in the revised text, it is demonstrated with more specific details in the original text with several examples in different chapters. For example, in Chapter II, Horace is having a conversation with his wife, Belle and she says "You are in love with your sister. What do the books call it? What sort of complex?" (Faulkner 1981, 16). Belle's utterance which refers to Horace's situation as a kind of complex has been deleted from the revised text. In the same chapter, there is also a part where Horace remembers his conversation with Narcissa two days before her wedding. He tries to discourage her and says "Don't do it Narcy. We both wont. Listen: we both wont. You haven't gone too far that you can't, and when I think what we with this house, and all it - Don't you see we can't?" (18). Horace's speech with his sister to discourage her from getting married is not included in the revised text. Horace's sister gets married four months after Horace returns from the army to a man she barely knows. Three months after the wedding her husband leaves her; eight months later she becomes a mother and a widow. It is obvious that his sister, Narcissa, married to stay away from her brother.

Horace's obsessive attachment to his sister and his horror about her being married to another man is exemplified in the following chapter as well. In Chapter III, Horace is talking to Miss Jenny, Narcissa's late husband's aunt, about Gowan Stevens and her sister ${ }^{1}$. Horace says: "Perhaps I do expect her to do me the constancy of being fickle. Perhaps she is going to marry again after all. Do you think she will?" (Faulkner 1981, 34). Horace now constantly worries that Narcissa might marry again and he regards his sister's possible marriage as an act of unfaithfulness to himself. This part of his speech with Miss Jenny is deleted from the revised text. In the following part of the same encounter, Horace says "I envy him ${ }^{2}$ the privilege. The privilege of not being her brother" (36). This sentence which is omitted from the revised text helps us understand how unfortunate Horace believes himself to be since he is Narcissa's brother.

Towards the end of the same chapter, Narcissa reads a newspaper aloud to the whole family and the reader is exposed to Horace's innermost thoughts while listening to her. "To Horace, listening, it seemed that they had never been so far asunder, so completely functioning in separate worlds, not even last night when she and Belle had seemed for the

\footnotetext{
${ }^{1}$ Horace meets Gowan in his sister's house the day before Gowan takes Temple to the distillery.

${ }^{2}$ Horace refers to Gowan.
} 
time interchangeable. He watched her quietly, wondering what he had expected of her. He could recapture none of it, not even the glib words, let alone the desire" (Faulkner 1981, 45). Horace seems to have replaced his wife with his sister in his dreams. He seems to have some very secret desires towards Narcissa. As it is clear with the examples above, Horace's relation with his sister has been heavily censored in the revised text.

The censorship in the revised text decentralizes Horace and his problems. Hence, the traces of the Freudian reading in the revised text are erased. As Horace moves back, Popeye gets a more central role and the relations between them and the other characters are reestablished

\section{The Results of a Reading Based on Toury's Norms of Translation}

The textual comparison between Sanctuary and Sanctuary: The Original Text identifies Faulkner's decisions during revision and these decisions display how the operational norms work in the revision process. Matricial norms are exemplified with reorganizations, additions and deletions in the revised text. It is difficult to make certain deductions about whether these decisions were taken with a source or target oriented approach, but still, it is possible to say that the deletion of Horace's feelings from the original text results from a target oriented approach as they are censored. A target oriented approach could also be the reason for the reorganization of the text, because the revised text is more precise and straightforward. The additions may also result from a target oriented approach as the added biography has affected the changing theme and the central characters of the revised book.

In terms of the textual linguistic norms, it is possible to say that the revised text has a lot in common with the original text. This conclusion can be grounded on Faulkner's other works. There is an obvious intertextual relation between Faulkner's different works in terms of "theme, symbol and tone" (Faulkner 1981, 298). In the afterword, Noel Polk explains that “. . . One of Faulkner's reasons for revising was to bring Sanctuary more in line with his current interests and preoccupations. Much of Sanctuary, even the published version, is a throwback to the themes and techniques of his earlier works, especially Flags in the Dust and The Sound and the Fury" (296-297). The editor believes that some materials deleted from Flags were reused in Sanctuary. Also, he speculates that “. . . Faulkner's work on Sanctuary 
affected the revision- perhaps even the decision to revise The Sound and the Fury" (298). Considering the revised Sanctuary's intertextual relation with Faulkner's other works in the source culture, it is possible to say that the choice of textual-linguistic material has been determined by a source culture oriented approach. Finally, in the revised text, “. . . Faulkner did not revise away from violence and horror, but rather toward them" (304). Although he agreed for a revision, it seems that Faulkner did not want to back away from the sensational plot in his original text.

The scope of this study makes it possible to reach conclusions about preliminary norms, as well. The fact that the editor refuses the first draft means a publishing policy exists. The novel was written at a time called the Prohibition Era (1920-1933) when the production, transportation and sale of alcohol were outlawed with the Eighteenth Amendment. The writers of that period were critical of this enforcement and literature was shaped by their realistic reflection of life. Realistic features of that era in the original text were probably the reason why the editor warned Faulkner about a possible jail imprisonment. However, even after this warning, Faulkner preserved outlaw personalities, clash of moral attitudes, class and racial issues in his revised version. Faulkner managed to have his work published after recontextualization and his effort to reflect the reality of the Prohibition Era was so successful that "the novel might be considered the foremost literary depiction of rural prohibition culture" (Drowne 2000, 64). It is possible to say that Faulkner re-contextualized his text in order to reach an agreement with the editor. He omitted the blunt expressions about Horace and his feelings towards his sister. However, while re-contextualizing Sanctuary, he made conscious decisions to preserve the realistic features that reflect the Prohibition Era. As a result, it is difficult to categorize Faulkner's revised text on one side of the source vs. target scale. In terms of the directness of the translation, it is not plausible to talk about an intermediate translation within the nature of this study as the subject matter is not an act of interlingual translation between two languages.

Finally, as for the initial norm, determinant for the previously discussed norms, there are two poles: adequate vs. acceptable. The stimulant for Faulkner to revise his text was definitely the editor's refusal and warning. Considering the fact that they reached an agreement to publish the revised text, it is possible to say that the revised version was acceptable. However, the points discussed about the previous norms display that Faulkner's approach is both source and target oriented. In terms of matricial norms, it is possible to say 
that reorganization, deletion and additions produce an acceptable text. Within the scope of textual linguistic norms, the revised text can be called adequate. Thus, as for operational norms, the revised text is both adequate and acceptable. This dualistic conclusion can be reached in terms of preliminary norms as well. Faulkner has managed to accord with the policy of the publisher while preserving the literary essence of his novel. To sum up, Sanctuary can be assessed as a translation both 'adequate' and 'acceptable.'

\section{Concluding Remarks}

In the afterword for Sanctuary: The Original Text, Noel Polk asks why Faulkner revised Sanctuary. He cannot provide the reader with a clear-cut answer and admits that "we of course may never know more than what we now know" (Faulkner 1981, 295). Polk thinks it might be because Faulkner needed money or recognized the untidiness of the passages (296).

This present paper tried to analyze this rewriting process and Faulkner's effort in terms of translation studies. The first thing observed in the revised text is the reorganization. One of the reasons for Faulkner to revise the text was to simplify it; therefore, it would be more economic and precise from the beginning to the end (302). In its original form, with flashbacks and long passages, it is a more complicated text. However, the revised text is more direct and economic. According to Karen Körning Zethsen (2009) “. . . in many kinds of intralingual translation, simplification is the key word. . . In order to simplify, the text may also be heavily paraphrased or restructured" (808). It is obvious that Sanctuary has been heavily restructured and simplification was possibly one of the underlying motives.

The editor, Noel Polk believes that "The early version is, essentially, a heavily Freudian study of Horace's sexual and emotional problems" (Faulkner 1981, 304). The revised text gets rid of his obsession with his sister. This deletion withholds Horace from his central role and signifies another character, Popeye. Hence, Popeye becomes a sort of mirror image for Horace from the very first chapter where the two characters meet across the spring. Also, with the inclusion of Popeye's biography at the end of the book, his status as a central character is empowered. The editor believes that "Faulkner's elevation of Popeye to a more central role has the further important effect of broadening the novel's themes: nature of evil itself: the power of darkness, the insufficiency of light" (304). With the addition of Popeye's 
background and the deletion of Horace's inner thoughts about his sister, it is possible to say that there is a change of theme, which affects the novel thoroughly. Translation strategies such as omitting, adding or restructuring are thought to be "more extreme than is generally the case in translation proper" (Zethsen 2009, 809). Therefore, it is possible to say that the given change of theme in the case of Sanctuary results from the radical use of these strategies.

The revision process, the revised text and Faulkner's effort have a lot in common with the act of translating, or rather 'self-translating.' The fact that this revision was carried out within the same language may be seen as ample evidence that the text is not a 'selftranslation.' However, the notion underlying this tendency needs to be reconsidered. Bilingualism is believed to be a precondition for a text to be regarded as a 'self-translation.' It is possible to claim that such a conditioning relates to the traditional view within translation studies. As in Jakobson's division, the transfer is required to be between languages for an act to be qualified as a 'proper translation.' Based on this perspective, the tradition limits 'selftranslation' only to 'interlingual translation' and excludes the writer's self-translating effort when it comes to 'intralingual translation.'

The present study has examined the presence of norms in the revision of Sanctuary. The findings from previous studies support the idea that norms can be studied and discussed within the frame of 'intralingual translations.' However, leading the argument towards one side of the binary oppositions may not provide a holistic explanation. As the case study exemplifies, a translation may include various features that may lead it to be considered both 'adequate' and 'acceptable' from different perspectives.

To sum up, considering all the similarities the revised text bears with 'intralingual translation,' it might be useful to relocate 'self-translation' from the 'interlingual' to 'intralingual.' And giving credit to Faulkner as a 'self-translauthor, ${ }^{3}$ the revised Sanctuary can be called an 'intralingual self-translation.' Hence, as the writer and the translator of the book, Faulkner can be considered an 'intr-auto-translauthor' which means an author who translates his own work into the same language. The creation of this neologism is based on the combination of a few concepts: to refer to the intralingual nature of translation, the first syllable 'intr-' has been used. 'Auto' refers to the 'self-translation' because the words 'auto'

\footnotetext{
${ }^{3}$ The word "translauthor" has been used to refer to a hybrid text producer and exemplified with a case study based on Don Quixote by Cervantes who retold and rewrote an already existing story. With a non-essentialist and deconstructivist approach, the researcher uses the neologism translauthor for Cervantes as he is both the author and the translator while producing his masterpiece (cf. Çulhaoğlu 2017).
} 
and 'self' are used interchangeably to refer to 'self-translation' in the literature (cf. Montini 2010). Finally, 'translauthor' refers to the person who authors and translates the same text. Taking this neologism into consideration, an author who translates his own work into another language would be called an 'inter-auto-translauthor.' Such new conceptual categorizations will be useful to expand the discussion within translation studies and to identify and consider cases which do not fit into the already existing categories. 


\section{References}

Beer, Ann. 1994. "Beckett's Bilingualism." In The Cambridge Companion to Beckett, edited by John Pilling, 209-221. Cambridge: Cambridge University Press.

Berk Albachten, Özlem. 2014. "Intralingual Translation: Discussions within Translation Studies and the Case of Turkey." In A Companion to Translation Studies, edited by Sandra Bermann and Catherine Porter, 573-585. West Sussex: Wiley-Blackwell.

- 2015. "The Turkish Language Reform and Intralingual Translation." In Tradition, Tension and Translation in Turkey, edited by Şehnaz Tahir Gürçağlar, Saliha Paker and John Milton, 165-180. Amsterdam: John Benjamins.

. 2019. "Challenging the Boundaries of Translation and Filling the Gaps in Translation History: Two Cases of Intralingual Translation from the 19th-century Ottoman Literary Scene." Chap. 10 in Moving Boundaries in Translation Studies, edited by Helle V. Dam, Matilde Nisbeth Brøgger, Karen Korning Zethsen. London: Routledge. Google Book.

Birkan Baydan, Esra. 2011. "Editing as Rewriting." Istanbul University Journal of Translation Studies 3: 53-78. http://dergipark.gov.tr/download/article-file/13474.

Çulhaoğlu, Tahsin. 2017. "A Portrait of The Translauthor in Don Quixote." Adryaman Üniversitesi Sosyal Bilimler Enstitüsü Dergisi 9 (25): 1-19. http://dergipark.ulakbim.gov.tr/adyusbd/article/view/5000192370/5000181518.

Derrida, Jacques. 1985. "Des Tours de Babel." In Difference in Translation, edited by Joseph F. Graham, 165-207. Ithaca, NY: Cornell University Press.

Drowne, Kathleen Morgan. 2000. "Spirits of Defiance: The Influence of National Prohibition on American Literature, 1920-1933.” PhD diss., University of North Carolina.

Ehrlich, Shlomit. 2009. "Are Self-Translators Like Other Translators?.” Perspectives: Studies in Translatology 17 (4): 243-255. doi:10.1080/09076760903404050.

Ersland, Anlaug. 2014. "Is Change Necessary? A Study of Norms and Translation Universals in Intralingual Translation." MA thesis, University of Bergen.

Faulkner, William. 1931. Sanctuary. New York: Random House.

1981. Sanctuary: The Original Text, edited by Noel Polk. New York: Random House.

Fowler, Doreen. 2004. "Faulkner's Return to the Freudian Father: Sanctuary Reconsidered." Modern Fiction Studies 50 (2): 411-34. 
Gottlieb, Henrik. 2005. "Multidimensional Translation: Semantics Turned Semiotics." In Proceedings of the Marie Curie EuroConferences MuTra: Challenges of Multidimensional Translation, edited by Heidrun Gerzymisch-Arbogast and Sandra Nauert, 1-29. Saarbrücken: MuTra https://www.euroconferences.info/proceedings/2005_Proceedings/2005_Gottlieb_Hen rik.pdf.

Grutman, Rainier. 2009. "Self-Translation." In Routledge Encyclopedia of Translation Studies, edited by Mona Baker and Gabriela Saldanha, 257-259. New York: Routledge.

Hermans, Theo. 1997. "Translation as Institution." In Translation as Intercultural Communication: Selected Papers from the EST Congress, Prague 1995 , edited by Mary Snell-Hornby, Zuzana Jettmarovâ and Klaus Kaindl, 3-20. Amsterdam: John Benjamins.

Hokenson, Jan Walsh and Marcella Munson. 2007. The Bilingual Text. History and Theory of Literary Self-Translation. Manchester: St. Jerome.

Jaillant, Lise. 2016. Modernism, Middlebrow and the Literary Canon: The Modern Library Series, 1917-1955. London: Routledge.

Jakobson, Roman. 1959. “On Linguistics Aspects of Translation.” In On Translation, edited by R. A. Drawer, 232-239. Cambridge, MA: Harvard University Press.

Karadağ, Ayşe Banu. 2010a. "Çevirmen ve Düzeltmen/Yayın Yönetmeni Dipnotlarıyla Osmanlı Tarihi'ni Yeniden Yazmak: Diliçi ve Dillerarası Çeviri Örneği." [To rewrite the Ottoman History with the footnotes of translator and redactor/chief editor: Sample of intralingual and interlingual translation.] In I. International Translation Studies and Terminology Conference Proceedings, edited by İlhami Sığırc1, Ayhan Güneş and Ziya Tok, 235-245. Kirıkkale: Vizyon Ofset.

. 2010b. "Görsel Dilde Çeviri Olgusuna Farklı Yaklaşımlar: Tercüman-ı Eşkâl." [Different approaches to translation in visual language: Tercüman-ı Eşkâl.] In The Tenth Language, Literature and Stylistics Symposium Proceedings, edited by Suna Ağıldere and Nurettin Ceviz, 688-694. Ankara: Bizim Büro.

—. 2011a. "Okur-Yazar/Çizer Çevirmen I." [Reader-writer/cartoonist translator I.] Çeviribilim Dergisi. 3:5.

- 2011b. "Okur-Yazar/Çizer Çevirmen II." [Reader-writer/cartoonist translator II.] Çeviribilim Dergisi. 4:9.

Karas, Hilla. 2016. "Intralingual Intertemporal Translation as a Relevant Category in Translation Studies." Target 28 (3): 445-466. doi:10.1075/target.28.3.05kar. 
Lefevere, André. 1992. Translation, Rewriting and the Manipulation of Literary Fame. London: Routledge.

Levey, David. 1996. "Samuel Beckett and the Silent Art of Self-Translation.” BIBLID 3 (4): 53-61.

Montini, Chiara. 2010. "Self-Translation." In Handbook of Translation Studies Volume 1, edited by Yves Gambier and Luc van Doorslaer, 306-308. Amsterdam: John Benjamins.

Phillips, Gene D. 1988. Fiction, Film and Faulkner: The Art of Adaptation. Knoxville: The University of Tennessee Press.

Shread, Carolyn. 2009. "Redefining Translation through Self-Translation: The Case of Nancy Houston." Translation in French Francophone Literature and Film, French Literature Series 26:51-66.

Sindicic- Sabljo, Mirna. 2011. "Beckett's Bilingualism, Self-Translation and the Translation of His Texts into the Croatian Language." JoLIE 4:163-180.

Sturrock, John. 1991. "On Jakobson on Translation.” In Recent Developments in Theory and History: The Semiotic Web, edited by Thomas A. Sebeok and Jean Umiker- Sebeok, 307-321. Berlin: Walter de Gruyter.

Toury, Gideon. 1986. "Translation: A Cultural-Semiotic Perspective." In Encyclopedic Dictionary of Semiotics, edited by Thomas A. Sebeok, 1111-1124. Berlin: Mouton de Gruyter.

1995a. Descriptive Translation Studies and Beyond. Amsterdam: John Benjamins.

. 1995b. "The Notion of 'Assumed Translation': An Invitation to a New Discussion." In Letterlijkheid, Woordelijheid / Literality, Verbality, edited by H. Bloemen, E. Hertog and W. Segers, 135-147. Antwerp: Fantom.

Zethsen, Karen Koning. 2009. "Intralingual Translation: An Attempt at Description”. Meta: Translators' Journal 54 (4): 795-812. 